\title{
Regulation of mucosal immune responses - The missing link in IBD?
}

\author{
Charles O Elson mD, Robert P McCabe Jr md, Kenneth W Beagley PhD, Almaz Sharmanov mD, \\ STEVEN L BRANDWEIN MD, BEN U RIDWAN MD, CASEY WEAVER MD, R PATRICK BUCY MD, \\ JERRY R MCGHEE MD, JOHN SUNDBERG PhD, EDWARD BIRKENMEIER MD
}

CO ELSON, RP MCCABE JR, KW BEAGLEY, et al. Regulation of mucosal immune responses - The missing link in IBD? Can J Gastroenterol 1996;10(2):105-109. Although the etiology of inflammatory bowel disease (IBD) remains unknown, a major working hypothesis is that it represents a dysregulated immune response to common enteric bacterial antigens. Until recently there has been a relative dearth of experimental models to study this hypothesis. However, exciting developments in experimental models of colitis, including spontaneous, transgenic and knockout mice, now allow this and other hypotheses to be tested. The regulation of mucosal immune responses is not well understood in the normal animal, much less in those with chronic intestinal inflammation. Clearly the CD4 Th1 and Th2 pathways are important in the host response to microbial pathogens, and recent data indicate that the intestinal mucosa seems to be a site of preferential Th2 responses toward exogenous antigens. Deletion of certain cytokine genes involved in maintaining this Th1/Th2 balance (interleukin [IL]-2, IL-10) resulted in colitis, although deletion of others (IL-4, interferon-gamma) that are also involved did not. Whether these cytokine gene deletions cause a dysregulation of the mucosal immune response has yet to be shown. However, the importance of regulation can be demonstrated in a model in which a normal $\mathrm{CD}^{+} \mathrm{T}$ cell subset (CD45Rb ${ }^{\text {high }}$ ) is transferred into syngeneic severe combined immunodeficiency syndrome recipients. This results in a striking colitis over the ensuing weeks with chronic diarrhea and wasting of the animals. If the reciprocal $\mathrm{CD} 4{ }^{+}$subset $\left(\mathrm{CD} 45 \mathrm{Rb}^{\text {low }}\right)$ is co-transferred or if whole $\mathrm{CD}^{+} \mathrm{T}$ cells are transferred no colitis ensues. Therefore, T cells capable of causing colitis are present in normal animals but are prevented from doing so by immunoregulatory mechanisms. The antigens that drive the colitis in several of these models (IL-2 knockout mouse, human leukocyte antigen B27/B2M transgenic rat) appear to be those of the normal enteric bacterial flora because germ-free animals do not get the disease. Spontaneously colitic C3H/HeJBir mice also show prominent reactivity to enteric bacterial antigens. There are major differences among inbred mouse strains in susceptibility to colitis. The genes involved are not yet identified, but newly available technologies should allow that. In summary, these new models provide an experimental foundation to one of the major hypotheses on the cause of IBD, and will allow dissection of the genetic, environmental and immune components contributing to chronic colitis.

Key Words: Colitis, Cytokine, Knockout, T cell

Le contrôle des réponses immunitaires de la muqueuse : Le chaînon manquant dans les MII

RÉSUMÉ : L'étiologie des maladies inflammatoires de l'intestin (MII) reste inconnue, mais une importante hypothèse est à l'étude, selon laquelle les MII seraient la manifestation d'un dérèglement de la réponse immunitaire à l'endroit d'antigènes bactériens entériques communs. Jusqu'à récemment, il y a eu peu de modèles expérimentaux pour tester cette hypothèse. Les progrès intéressants enregistrés par les modèles expérimentaux de colite, y compris les souris manifestant spontanément la maladie, les souris transgéniques et à gène supprimé voir page suivante

Departments of Medicine, Microbiology and Pathology, University of Alabama at Birmingham, Birmingham, Alabama, USA and The Jackson Laboratory, Bar Harbor, Maine, USA

Correspondence: Dr CO Elson, Division of Gastroenterology, UAB Station, Birmingham, AL 35294-0007, USA. Telephone 205-934-6060, fax 205-934-8493

This paper was presented at the Basic Research and Clinical Implications in IBD meeting, April 6 to 9, 1994, held in Victoria, British Columbia. This paper has also been published in Sutherland LR, et al, eds. Inflammatory Bowel Disease: Basic Research, Clinical Implications and Trends in Therapy. Boston, Dordrecht and London: Kluwer Academic Publishers, 1994 
(knockout) permettent désormais de vérifier ces hypothèses. Les mécanismes de contrôle des réponses immunitaires de la muqueuse sont encore mal élucidés chez l'animal normal, et encore moins chez les sujets atteints d'inflammation intestinale chronique. De toute évidence, les voies des CD4 Th1 et Th2 jouent un rôle important dans la réponse de l'hôte aux organismes pathogènes, et selon les données récentes, c'est surtout au niveau de la muqueuse intestinale que semblent se manifester les réponses Th2 à l'endroit des antigènes exogènes. L'élision de certains gènes des cytokines responsables de l'équilibre Th1/Th2 (interleukines, IL-2 et IL-10) a entraîné la colite, contrairement à l'élision d'autres gènes (IL-4, interféron gamma). Il reste à démontrer si l'élision de ces gènes des cytokines provoque un dérèglement de la réponse immunitaire de la muqueuse. L'importance des mécanismes régulatoires peut toutefois être démontrée dans un modèle où un sous-groupe de cellules $\mathrm{T} \mathrm{CD} 4^{+}\left(\mathrm{CD} 45 \mathrm{Rb}^{\text {high }}\right)$ est transféré à des receveurs atteints d'immunodéficience congénitale combinée sévère. Il en résulte une colite importante au cours des semaines suivantes, accompagnée de diarrhée chronique et d'amaigrissement. Si le sous- groupe $\mathrm{CD}^{+}{ }^{+}$réciproque $\left(\mathrm{CD} 45 \mathrm{Rb}^{\text {low }}\right)$ est cotransféré, ou si toutes les cellules T CD4 ${ }^{+}$sont transférées, la colite ne se manifeste pas. Les cellules $\mathrm{T}$ aptes à provoquer la colite sont donc présentes chez les animaux normaux mais en sont empêchées par des mécanismes immunorégulateurs. Les antigènes responsables de la colite dans plusieurs de ces modèles (souris à gène IL-2 supprimé, rat transgénique par l'antigène du leucocyte humain B27/32M) semblent être ceux de la flore bactérienne entérique normale, parce que les animaux indemnes de pathogènes ne deviennent pas malades. Les souris $\mathrm{C} 3 \mathrm{H} / \mathrm{HeJBir}$ qui développent spontanément une colite réagissent aussi de façon marquée aux antigènes bactériens entériques. Il y a certaines différences majeures entre les lignées pures de souris pour ce qui est de leur fragilité à l'égard de la colite. Les gènes en cause ne sont pas encore identifiés, mais les nouvelles technologies nous y conduiront. En résumé, ces nouveaux modèles forment la base expérimentale de l'une des principales hypothèses sur l'étiologie des MII, et permettra la dissection des composantes génétiques, environnementales et immunitaires de la colite chronique.
$\mathrm{T}$ he intestine is quite distinct from other organs that are involved in chronic inflammatory/autoimmune diseases. Mucosal surfaces, in particular the intestinal mucosa, are the major interface between the immune system and the antigens and microbes of the external environment. To deal with this challenge, a specialized mucosal immune system has evolved which is marked by certain distinct features (1). The massive antigenic challenge and the specialized features of the mucosal immune system add further complexity to our potential understanding of the mechanisms of inflammatory bowel disease (IBD) compared with diseases such as autoimmune diabetes or multiple sclerosis, which affect organs that are largely sequestered from antigenic challenge.

\section{CONCEPTS OF MUCOSAL IMMUNE SYSTEM REGULATION}

An understanding of the mucosal immune system and how it is regulated is thus very important to our understanding of IBD. There are a number of important aspects or concepts of mucosal immune regulation that provide a context or framework for the understanding of IBD (Table 1). First, there is enormous and continuous immunoglobulin (Ig) A response in the mucosa. Some $60 \%$ of all the immunoglobulin made daily is $\operatorname{IgA}$; quantitatively this represents about 3000 to $4000 \mathrm{mg} /$ day of IgA, produced predominantly in the gut (2). The number of gut lymphoid cells producing IgA has been estimated at $10^{10} / \mathrm{m}$ of small intestine in humans (3). Second, consistent with this strong humoral response in the mucosa, intestinal mucosa appears to be a preferential site for Th2-type $T$ cell responses. Thus, an antigen encounter in the gut mucosa tends to generate predominantly a Th2 response, whereas that same antigen given systemically tends to elicit a predominantly Th1 response (4). The Th1 and Th2 pathways of $T$ cell responses are important in the outcome of the host response to various microbial pathogens, and disturbance of the balance between these pathways may result in chronic inflammatory disease $(5,6)$. Third, the en-

\section{TABLE 1}

\section{Concepts of mucosal immune regulation}

\author{
Enormous secretory immunoglobulin A response \\ Th1 versus Th2: gut mucosa a preferential Th2 site \\ Environment differs at various mucosal sites \\ Mucosal tolerance prevents response to many antigens \\ Potent regulatory mechanisms restore homeostasis after injury
}

vironmental exposure of different regions of the mucosa varies tremendously. For example, the antigenic environment in the small bowel is quite different from that in the colon. Perhaps related to this, the mucosal immune system in the mouse colon comprises cells that are quite distinct from those in the small bowel (7). These differences may relate to a need to respond to a different assortment of food and microbial antigens at these different sites. Whether similar differences exist in humans is unknown. Fourth, the mucosal immune system does not respond to every antigen that transits the bowel; many antigens elicit tolerance rather than immunity. This is demonstrated readily by feeding an antigen before systemically immunizing with the same antigen. Animals fed the antigen before immunization have a markedly reduced response. Mechanisms underlying such 'oral tolerance' remain unclear, but clonal anergy and $\mathrm{CD} 8^{+} \mathrm{T}$ cells secreting the inhibitory cytokine transforming growth factor-beta have both been reported (8). Last, there are potent mechanisms in place that rapidly restore homeostasis following injury to the bowel (9). For example, after enemas of irritant chemicals, these mechanisms rapidly restore the epithelial barrier, repair the tissue matrix and downregulate the potentially deleterious immune cell populations. Each of these various aspects of mucosal immune regulation is germane to and important in the understanding of potential abnormalities occurring during IBD. 


\section{NEW MOUSE MODELS OF CHRONIC COLITIS}

Although the pathogenesis of IBD remains obscure, Crohn's disease and ulcerative colitis clearly are complex disorders with immune, genetic and environmental components. It has been difficult to study the early events and interactions among these components leading to chronic intestinal inflammation; however, a number of recent developments now make such studies possible. A number of new mouse models of chronic colitis have recently become available, several due to advances in genetic technology that allow targeted gene inactivation in mice. As shown in Table 2, deletions of certain genes of the immune system resulted in mice that spontaneously develop chronic intestinal inflammation. Interestingly, certain of these genes encode cytokines that are involved in maintaining the Th1/Th2 balance (5). Although deletion of certain of these genes, such as IL-2 (10) and IL-10 (11), resulted in mice that develop colitis, deletion of others that are also involved in maintaining the Th1/Th2 balance, such as IL-4 and interferon-gamma, did not. Likewise, colitis resulted in mice rendered deficient in $\mathrm{T}$ cell receptor-alpha-beta-bearing $\mathrm{T}$ cells by deletion of the $T$ cell receptor alpha chain (12), but colitis has not been reported to occur in nude mice which also lack T cells. Although a unifying pathogenesis has been advanced to explain the pathogenesis of colitis in these knockout mice, it seems more likely that there are multiple pathways that can result in chronic intestinal inflammation. Whether these immune gene deletions are causing disease by disrupting the normal regulation of mucosal immune responses is an attractive hypothesis that will require further experimental study.

Some insights into the importance of immune regulation relative to chronic intestinal inflammation have come from adaptation of the trinitrobenzenesulphonic acid (TNBS)/ ethanol model to mice. This model originated in Canada and was applied initially to studies in rats (13). TNBS is one of a group of contact-sensitizing allergens that have been used for years to study the mechanisms of delayed hypersensitivity. These compounds are covalently reactive chemicals that attach to tissue proteins and induce a CD4 ${ }^{+} \mathrm{T}$ cell reaction to the resulting hapten-modified self antigens (14). One advantage of this system is that the antigen or agent is known and well defined; thus both the specific and nonspecific response to it can be measured and their regulation studied. We have recently adapted this system to the mouse. One of the interesting observations made in adapting this system is that there are major differences in susceptibility among inbred strains. For example, $\mathrm{C} 3 \mathrm{H} / \mathrm{HeJ}$ and BALB/C strains are quite susceptible, whereas $\mathrm{C} 57 \mathrm{Bl} / 6$ and DBA2 strains are very resistant. Mice of the resistant strains develop skin test reactivity to the allergen but rapidly downregulate the inflammation in the colon such that within days of the challenge enema, the mucosa looks quite normal. Moreover, spontaneous production of cytokines by lymph node cells draining the distal colon is found in susceptible mice, but not at all in mice of the resistant strains. Despite this being a lesion mediated by $\mathrm{CD}^{+} \mathrm{T}$ cells, there are dramatic changes in the $\mathrm{B}$ cell compartment during TNBS-
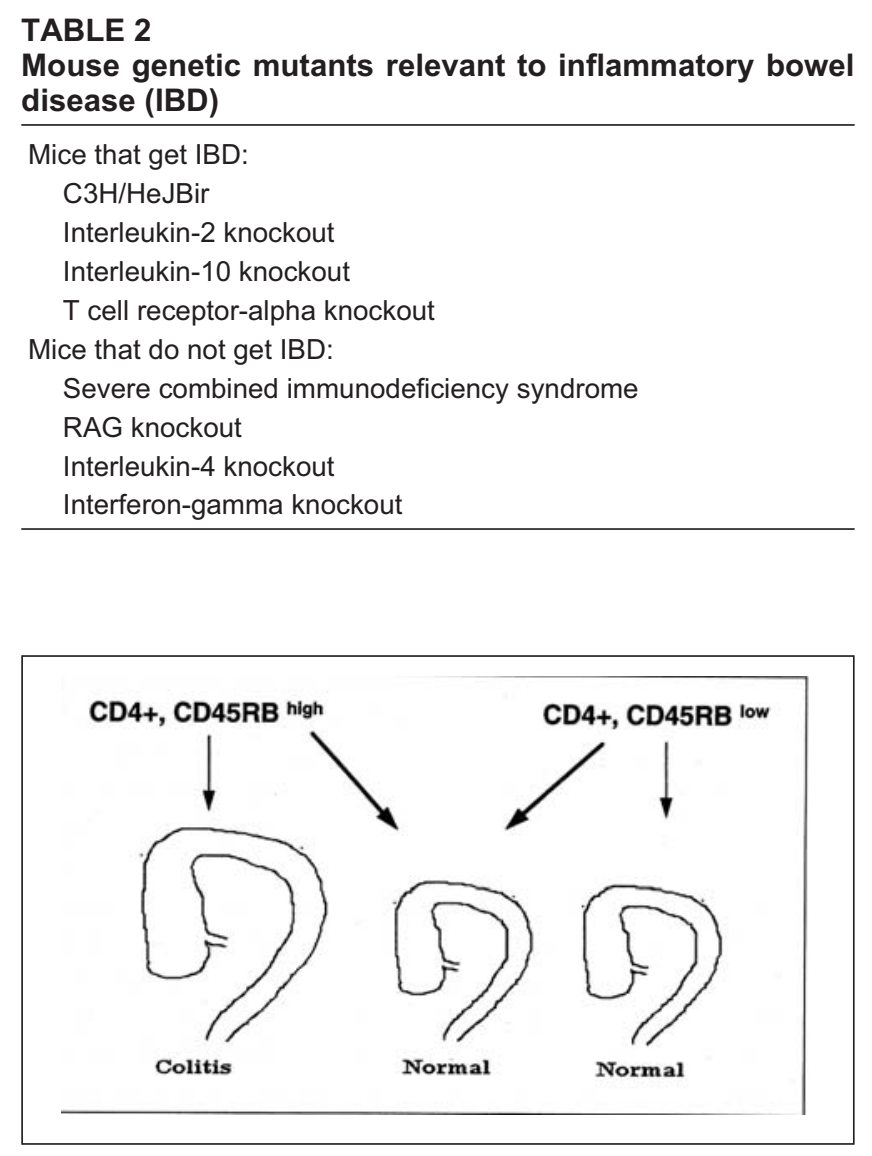

Figure 1) The outcome of autologous $\mathrm{CD}^{+}, \mathrm{CD} 45 \mathrm{RB}$ cell transfers to severe combined immunodeficiency syndrome recipients. Adoptive transfer of $\mathrm{CD}^{+}$, CD45RB high T cells results in a striking colitis after five to 10 weeks. Transfer of $\mathrm{CD} 4{ }^{+} \mathrm{CD} 45 \mathrm{RB}{ }^{\text {low }} \mathrm{T}$ cells does not cause disease. Co-transfer of both subsets abrogates the disease seen after transfer of only the CD4+ CD45RB high subset

induced colitis. This B cell response includes a prominent shift of B cells from spleen and Peyer's patch into the lesions, the draining lymph node and the mesenteric lymph node. Only about half of this B cell response can be attributed to the anti-2,4,6-trinitrophenol (anti-TNP) response, indicating that there is a large concomitant polyclonal response (unpublished data). The antibody response to the hapten is mainly of the IgG2a subclass, which is consistent with a predominant Th1 T cell immune reaction (unpublished data).

Feeding contact allergens to mice results in a state of oral tolerance (15). We recently completed a series of experiments addressing whether the induction of oral tolerance with TNBS would affect the anti-TNP immune response or the severity of TNBS-induced colitis. Mice were fed $10 \mathrm{mg}$ of soluble TNBS on two occasions before the sensitizing and challenge enema with TNBS and ethanol. The anti-TNP response in various tissues was analyzed in tolerized versus control mice using enzyme-linked immunospot assay technique. Prior feeding of TNBS abrogated the IgG anti-TNP response, although the local mucosal IgA anti-TNP response was maintained. More interestingly, the induction of oral tolerance to TNBS significantly ameliorated the severity of 
the inflammation in subsequent TNBS-induced colitis (unpublished data). These results indicate that it may be possible to exploit the intrinsic regulatory mechanisms of the mucosal immune system in the treatment of chronic intestinal inflammation.

A second mouse model has recently been described that is highly relevant to the present discussion. In this model, a subset of $\mathrm{CD}^{+} \mathrm{T}$ cells that expresses a high level of the CD45RB surface antigen are transferred into syngeneic severe combined immunodeficiency syndrome (SCID) recipients $(16,17)$ (Figure 1). Mice with the SCID mutation lack $B$ cells or $T$ cells but have intact innate immunity consisting of macrophages, neutrophils and natural killer cells. After a lag phase of some weeks, the recipients begin to lose weight due to the development of a prominent colitis. In the colon there is infiltration of CD4 ${ }^{+} \mathrm{T}$ cells and macrophages, crypt hyperplasia, mucin depletion and scattered crypt abscesses. The clinical course of these animals is that of progressive weight loss, inanition and death. This pathology is very similar to that seen in cyclosporin A-induced colitis (18). If the reciprocal $\mathrm{CD}^{+}$subset, which expresses low levels of the CD45RB surface marker, is transferred to SCID mice, or if whole $\mathrm{CD}^{+}{ }^{+} \mathrm{T}$ cells are given, no colitis ensues, although the animals become populated with these $\mathrm{T}$ cells. If both $\mathrm{CD}^{+} \mathrm{T}$ cell subsets are given together $\left(\mathrm{CD} 45 \mathrm{RB}{ }^{\text {high }}\right.$ plus CD45RB $\left.{ }^{\text {low }}\right)$, no colitis occurs. There are two major lessons from these experiments. First, T cells present in normal mice are capable of causing chronic colitis. One can detect the presence of these cells only in an environment lacking immune regulatory mechanisms. The second lesson is that regulatory $\mathrm{T}$ cells, also present in normal mice, prevent the induction of colitis by the former effector $\mathrm{T}$ cells.

A question that immediately jumps to mind is, what is the antigen driving chronic colitis in this model? The same question could be asked in human IBD. The antigens have yet to be identified in the CD45RB transfer model, but there is information from some of the other genetic models. The IL-2 knockout mouse does not develop colitis when rendered germ-free (10), implicating the normal enteric bacterial flora in this disease. Interestingly, the bowel lesions in the IL-2 knockout mouse are limited to the colon and do not affect the small bowel. This indicates that the localization of the enteric flora mainly in the colon is what limits the disease to this segment of the intestine. The IL-10 knockout mouse has a greatly reduced pathology when rendered specific pathogen-free (11). The human leukocyte antigen

\section{REFERENCES}

1. MacDermott RP, Elson CO, ed. Mucosal Immunology I. Philadelphia: WB Saunders Co, 1991.

2. Mestecky J, McGhee JR, Elson CO. Intestinal IgA system. Immunol Allergy Clin North Am 1988;8:349-68.

3. Brandtzaeg P. Overview of the mucosal immune system. In: Mestecky J, McGhee JR, ed. New Strategies for Oral Immunization. New York: Springer-Verlag, 1989:13-25.

4. Xu-Amano J, Jackson RJ, Staats HF, et al. Helper T cell subsets for IgA responses. Oral immunization with tetanus toxoid and cholera toxin as adjuvant selectively induces Th2 cells in mucosa-associated tissues. J Exp Med 1993;178:1309-20.

5. Mosmann TR, Coffman RL. TH1 and TH2 cells: different patterns of
B27//32 microglobulin transgenic rat does not develop enteritis or arthritis when made germ-free (19). Lastly, spontaneous colitis in $\mathrm{C} 3 \mathrm{H} / \mathrm{HeJBir}$ mice is associated with a strong response to antigens of the normal enteric flora $(20,21)$. A reasonable unifying hypothesis that fits all of these observations is that chronic colitis is the result of a dysregulated mucosal immune response to enteric bacterial antigens normally present in the colon. This hypothesis has been advanced for several years but until recently there has been a relative dearth of experimental models in which to test it. These newer models of colitis should allow a definitive answer to it, as well as allow the definition of the cellular and molecular mechanisms involved.

\section{'COGNITIVE PARADIGM'}

Irun Cohen (22) has advanced a novel hypothesis which he has termed the 'cognitive paradigm', in which pre-formed internal images of external antigens guide and restrict the process of clonal activation. Thus, the immune system is seen as representing an 'immunological homunculus', ie, the immune system exists to protect us against microbes, and the receptors of the immune system in essence are the mirror image of the microbial antigenic universe. Under this paradigm, autoimmunity is seen as the price that humans pay for effective protection against microbes, eg, via microbe-autoantigen cross-reactivity. When one considers that the major interface between microbial antigens in the immune system resides in the intestine, this paradigm has interesting implications for our understanding of chronic intestinal inflammation, eg, is IBD the price that humans pay for effective mucosal immunity against microbes?

\section{CONCLUSIONS}

An understanding of mucosal immune regulation is crucial to understanding IBD. T cells can mediate chronic colitis in at least two mouse models and will likely be found to do so in others. Genetic susceptibility plays a major role in disease expression in such models and probably in humans. The possibility of mapping genetic loci responsible for such susceptibility in mice is an exciting prospect due to the strong homology between mouse and human. These newer mouse models provide a good deal of support for the hypothesis that a dysregulation of the mucosal immune response to common enteric bacterial antigens may be the fundamental underlying defect in the pathogenesis of chronic intestinal IBD.

lymphokine secretion lead to different functional properties. Ann Rev Immunol 1989;7:145-73.

6. Heinzel FP, Sadick MD, Holoday BJ, Coffman RL, Locksley RM

Reciprocal expression of interferon gamma or interleukin 4 during the resolution or progression of murine leishmaniasis. Evidence for expansion of distinct helper T cell subsets. J Exp Med 1989;169:59-72.

7. Beagley KW, Fujihashi K, Lagoo AS, Elson CO. Regional differences in mucosal lymphoid cells of murine small vs. large bowel. Gastroenterology 1992;102:A593.

8. Miller A, Lider O, Roberts AB, Sporn MB, Weiner HL. Suppressor T cells generated by oral tolerization to myelin basic protein suppress both in vitro and in vivo immune responses by the release of 
transforming growth factor beta after antigen-specific triggering. Proc Natl Acad Sci USA 1992;89:421-5.

9. Dielemann LA, Elson CO, Tennyson GS, Beagley KW. Cytokine expression during acute colonic injury in mice. Gastroenterology 1992;102:A616.

10. Sadlack B, Merz H, Schorle H, Schimpl A, Feller AC, Horak I. Ulcerative colitis-like disease in mice with a disrupted interleukin-2 gene. Cell 1993;75:253-61.

11. Kuhn R, Lohler J, Rennick D, Rajewsky K, Muller W. Interleukin-10-deficient mice develop chronic enterocolitis. Cell 1993;75:263-74

12. Mombaerts P, Mizoguchi E, Grusby MJ, Glimcher LH, Bhan AK, Tonegawa S. Spontaneous development of inflammatory bowel disease in $\mathrm{T}$ cell receptor mutant mice. Cell 1993;75:1-20.

13. Morris GP, Beck PL, Herridge MS, Depew WT, Szewczuk MR, Wallace JL. Hapten-induced model of chronic inflammation and ulceration in the rat colon. Gastroenterology 1989;96:795-803.

14. Miller SD, Butler LD, Cleveland RP, Moorhead JW, Claman HN, Chiller JC. T-cell responses induced by the parenteral injection of antigen-modified syngeneic cells. II. Mechanisms, specificity, and cellular analysis of 2,4,6-trinitrophenol (TNP)-specific cytolytic response priming by intravenous versus subcutaneous injection with TNP-modified syngeneic cells. Cell Immunol 1983;82:378-93.

15. Asherson GL, Zembala M, Perera MACC, Mayhew B, Thomas WR
Production of immunity and unresponsiveness in the mouse by feeding contact sensitizing agents and the role of suppressor cells in the Peyer's patches, mesenteric lymph nodes and other lymphoid tissues. Cell Immunol 1977;33:145-55.

16. Powrie F, Leach MW, Mauze S, Caddle LB, Coffman RL. Phenotypically distinct subsets of $\mathrm{CD} 4+\mathrm{T}$ cells induce or protect from chronic intestinal inflammation in C.B-17 scid mice. Eur J Immunol 1993;5:1461-71.

17. Morrissey PJ, Charrier K, Braddy S, Liggitt D, Watson JD. CD4+ $\mathrm{T}$ cells that express high levels of CD45RB induce wasting disease when transferred into congenic severe combined immunodeficient mice. Disease development is prevented by cotransfer of purified CD4+ T cells. J Exp Med 1993;178:237-44.

18. Bucy RP, Xu XY, Li J, Huang GQ. Cyclosporin A-induced autoimmune disease in mice. J Immunol 1993;151:1039-50.

19. Taurog JD, Richardson JA, Croft JT, et al. The germfree state prevents development of gut and joint inflammatory disease in HLA-B27 transgenic rats. J Exp Med 1988;180:2359-64.

20. Sundberg JP, Elson CO, Bedigian H, Birkenmeier EH. Spontaneous, heritable colitis in a new substrain of $\mathrm{C} 3 \mathrm{H} / \mathrm{HeJ}$ mice. Gastroenterology 1994;107:1726-35.

21. Brandwein SL, McCabe RP, Dadrat A, et al. Immunologic reactivity of colitic $\mathrm{C} 3 \mathrm{H} / \mathrm{HejBir}$ mice to enteric bacteria. Gastroenterology 1994;106:A656.

22. Cohen IR. The cognitive paradigm and the immunological homunculus. Immunol Today 1992;13:490-4. 


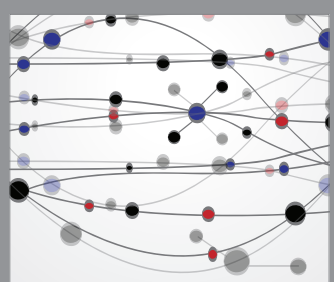

The Scientific World Journal
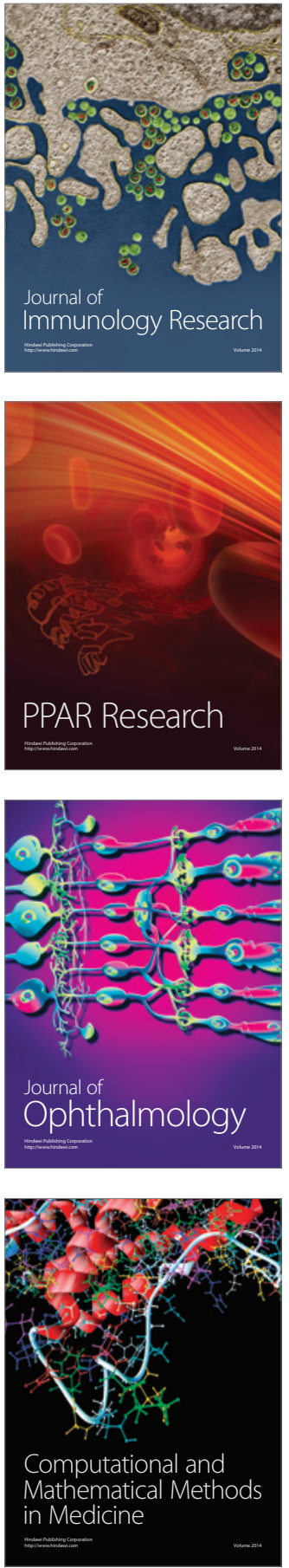

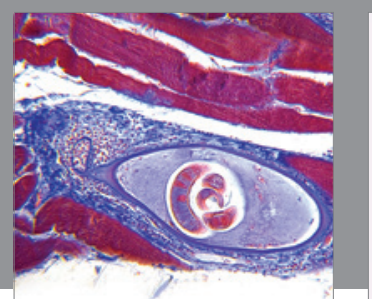

Gastroenterology Research and Practice

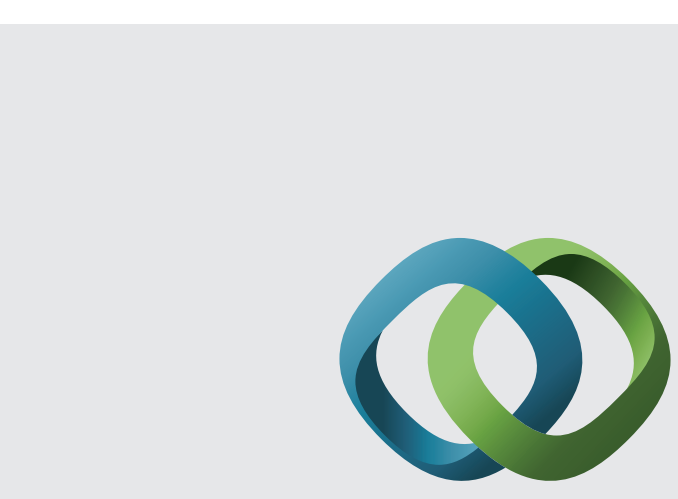

\section{Hindawi}

Submit your manuscripts at

http://www.hindawi.com
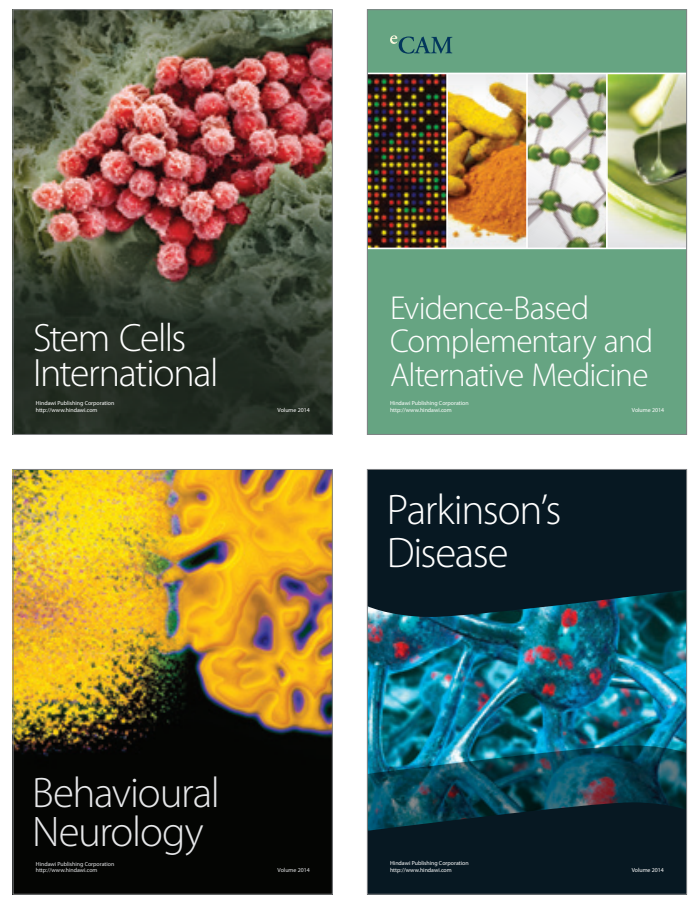
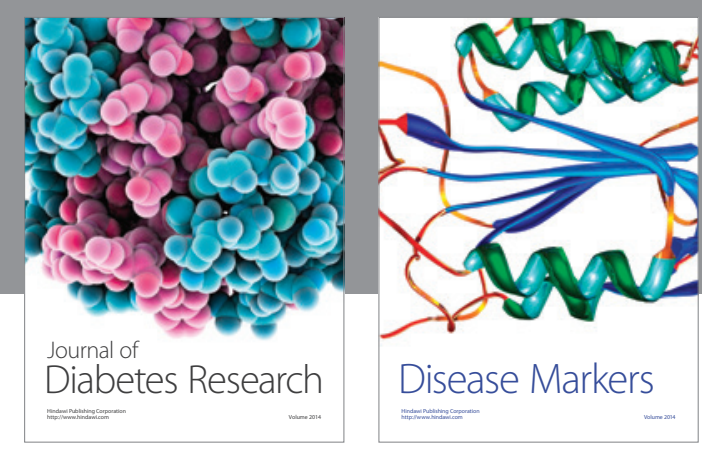

Disease Markers
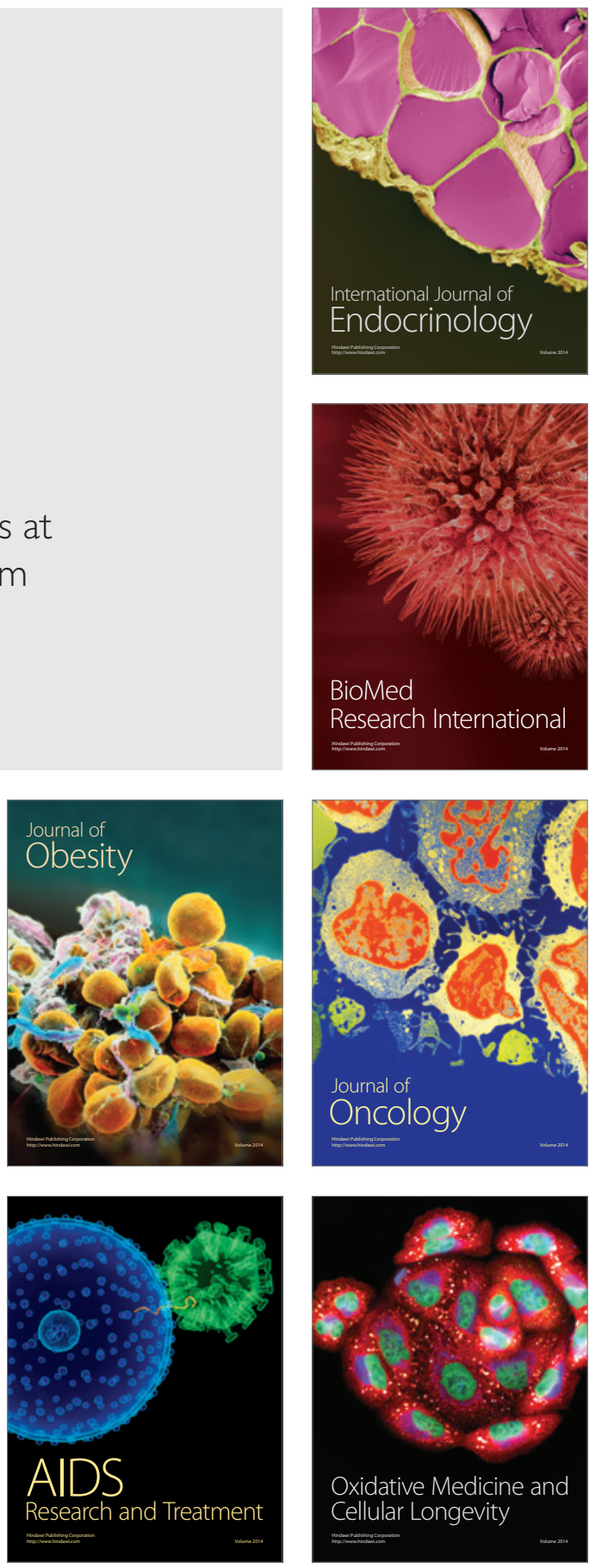